\title{
Essential elements of human rights in Buddhism
}

\begin{abstract}
Uttamkumars Bagde
Applied Microbiology Laboratory, Department of Life Sciences, University of Mumbai, Vidyanagari, Santacruz (East) Mumbai- 4000098, India.

Received 16 July 2013; Accepted 9 April, 2014; Published May 2014

Broadly speaking elements and principles of human rights are incorporated in teachings of the most religions of the world including Buddhism. Notion of a right is very much there in Buddhism. The elements incorporated in social message of Buddha are part and parcel of modern day principles of human Rights incorporated in many international declarations, covenants, protocols and constitutions of most of the countries of today. Buddha succeeded in discovering the antidote of all sufferings in the form of Dhhama, a collection of very simple and clear elements of natural truth for the restoration of human rights and fundamental freedom. There is intimate and vital relationship of Buddhist norm of Dhamma with that of human Rights. Buddhism subscribes to universal human rights concept and all the articles of universal declaration of human rights (UNDHR) are in harmony with early Buddhist teachings in letter and spirit. Human Rights as construed in the modern era are compatible with Buddhist ethics. Certain values embodied in the notion of right are better served by the notion of right in the Noble Eight fold Path given by Buddha. Human rights notion is an extension of human nature. Buddhism indeed is supreme law of all laws existed so far in the province of human right protection and fundamental freedom. Duties and rights are correlative and reciprocal. Buddhism is as such committed to the cause of human rights.
\end{abstract}

Key words: Buddhism, human rights, Dhamma of Buddha, duties and rights.

\section{INTRODUCTION}

It is contended that Buddhism concerns more with other issues than Human Rights. Moreover, concern for human rights is a post religions phenomenon which has more to do with secular ideologies and power politics than religion and therefore it is unreasonable to accuse Buddhism of neglect in this area. Also much of the Buddhist literature remains untranslated, hence there may be hidden treasures still undiscovered in this area and many elements of human rights could be found in Buddhism.

By meaning right is objectively true or right or straight or upright which is applied metaphorically in a moral context. The primary moral sense of right was a standard or measure for conduct. Right indicates right morally, straight or true that meets the standard of rectitude or rightness. In other way, it is something done by a person because it is his right or it is done because the person has right to do it. Hence, even if right things are incurporated in religious philosophy that means those right things are also rights of the person. Broadly speaking elements or principles of human rights are incorporated either expressly or impliedly in teachings of the most religions of the world including Buddhism. Transition of moral use of right to the notion of right for personal entitlement took place in the West in form of watershed

\section{E-mail: bagdeu@yahoo.com}

Author(s) a gree that this artic le rema in pemanently open access under the terms of the Creative Commons Attribution License 4.0 Intemational Lic ense 
that happened during the late middle Ages. It was the concept of natural rights then that got evolved towards the end of Seventeenth century as reported by John Locke. Earlier, use of this connotation was in Thirteenth century and Grotius used it in Seventeenth century. Modern use of right emanated in Hobbes writings in the middle of seventeenth century. Natural rights are in alienable and have not been conferred on person by any judicial or political entities and hence someone cannot be deprived of his/her rights by these or other entities. Concept of natural Rights of Seventeenth and Eighteenth centuries culminated in the notion of human Rights of eighteenth Centuries that continues to prominence in $20^{\text {th }}$ and $21^{\text {st }}$ Centuries.

It is historical process through which concept of human rights evolved. Moreover the idea was not entirely new and there has been influence of Christian doctrine on it in many respects too. Also philosophical justification of Human Rights has been found in other philosophies and religions including Buddhism (Demien 1995). The basic concept of human rights envisages right as something personal to individual, it may be thought of as something an individual has.

By definition, Right is benefit which confers upon its holder either a claim or liberty. Modern concept of human rights is however many faceted concept. In metaphorical and moral sense right word is seen in Buddhist as well as other languages. However, in Pali there is no word that actually conveys idea of rights, as subjective entitlement. But the notion of rights may be distributed among a variety of terms in Buddhist languages, as in Latin language it could be librettos, jurisdictio, dominium etc. Also cultures may depict concept of rights without having vocabulary which expresses the concept. Thus, concept may be used rather than have it in words and persons might have used the concept of right without explicitly having a single word for it. Like English terms right and duty are translated as ought, concept of right may exist where a word for it does not. Dharma in Buddhism conveys what is right and just in all contexts and from all perspectives. The word Religion according to Dr. Ambedkar is an unidentified word with no fixed meaning and that is because religion has passed through many stages. The concept of each stage was called religious thought. The concept at one stage has not had the same connotation which it had in the preceding stage. Its meaning is likely to differ in the succeeding stages. The concept of religion was never fixed but it varied from time to time. Similarly the concept and scope of Human Rights is ever changing. It is dynamic and liberal in nature and wider in its scope.

As Buddha and Buddhism is concerned, anything that does not relate to man's welfare cannot be accepted to the word of Buddha. According to Buddha, his Dhamma (religion) had nothing to do with God and soul. His Dhamma has nothing to do with life after death
(Ambedkar 1984, 1992). The Centre of Dhamma is man and relation of man to man in his life on earth. The world is full of suffering and to remove this suffering from the world is the only purpose of Dhamma. Nothing else is Dhamma. According to Dhamma if every person followed the path of purity, the path of righteousness and the path of virtue, it would bring end of all sufferings. According to path of purity the principles recognized by it are: Not to injure or kill, not to steal or appropriate to one selfanything which belongs to another, not to speak untruth, not to indulge in lust, not to indulge in intoxicating drinks. According to the path of Righteousness there are eight constituents called Ashtang Marg that is, (i) Right look (ii) Right Intension (iii)Right Speech (iv) Right Action (v) Right Effort (vi) Right Means of Livelihood (vii) Right Mindfulness and (viii) Right Concentration. According to Buddha the path of virtues meant - (i) Sila (moral temperament, not to do evil), (2) Dana ( giving ones possessions even one's life for the good of others), (3) Uppekha ( detachment from indifference), (4) Nekkhama (renunciation of the pleasure of the world), (5) Virya (right endeavor), (6) Khanti (is forbearance, not to meet hatred by hatred), (7) Succa (is truth in speech and never to tell a lie), (8) Adhithana (resolute determination to reach the goal), (9) Karuna (loving kindness to human beings), (10) Maîtri (fellow feeling to all living beings) Anand, (2002).

According to some Samadhi is Buddha's principle teaching or Vippassana, is his main teaching, to some it is metaphysics, mysticism or selfish abstraction from world, to some it is systematic repression of every impulse and emotion of the heart. This divergence of views is astonishing. On the other hand many consider that Buddha gave a social massage through his dhamma. The massage include, teaching of Ahinsa (nonviolence), peace, justice, love, liberty, equality and fraternity etc. which clearly and conclusively indicate that Buddha very much gave a social massage through his teachings. The elements incorporated in his social massage are part and parcel of modern day principles of human Rights incurporated in many international declarations, covenants, protocols and constitutions of most of the countries of today. According to him Dhamma means Dhammawhich is not Adhamma and which is Sadhamma. Dhamma means to maintain purity of life, to reach perfection in life, to live in Nibbana (that means idea of happiness of a sentient being, when in Samsara (when alive), exercise of control over the flames of the passions which are always on fire. Unhappiness is the result of greed and greed is the bane of life of those who have as well as of those who have not. Nibbana is another name of righteous life. To give up craving, to believe that all compound things are impermanent, to believe that Karma is the instrument of moral order. This also means belief in supernatural, belief in God, belief in soul, union with Brahma is a false Dhamma, belief in sacrifices, belief based on speculation, is not Dhamma, belief in infallibility 
of books of Dhamma is not Dhamma. According to Buddha Saddhamma among other things include making the world a kingdom of Righteous, making learning open to all, breaking down barriers between man and man, worth and not birth is the measure of man. Dhamma to be saddahmma must promote equality between man and man. It is Saddhamma when it touches Maitri (love for living beings). Dhamma to be Saddhamma must pull down all social barriers. As to Buddha's sense of equality and equal treatment is concerned, he never claimed any exception and whatever rules the Blessed Lord made were voluntarily and willingly accepted by him and followed by him as much as by the bhikkhu.

United Nations conceived the philosopthy of the protection of human rights and fundamental freedom as a reaction of international community against holocaust created in the World War II. Preamble to the UN charter reaffirms faith in fundamental human rights and in the dignity and worth of human person, in the equal rights of men and women. Spiritual horizon of India was under cloud when Prince Siddharth (Buddha) was born. Humanity was eclipsed. Under the religious sanction of the Brahmanical order, human sacrifice and animal sacrifice were rampant and abated. Hatred and discrimination against each other was legally nourished cunningly.

Bonded labor, exploitation, slavery, sexual abuses were common. Siddharth Buddha was grieved to see this stage. Finally he succeeded in discovering the antidote of all sufferings in the form of Dhhama, a collection of very simple and clear elements of natural truth for the restoration of human rights and fundamental freedom.

Present study envisages critical analysis of Human rights perspectives in Buddhist philosophy, essential elements of human rights expressed and implied in Buddhism and its compatibility with modern concept of human rights and universal declaration of human rights.

\section{Human Rights concept as per UDHR 1948}

Universal declaration of human rights 1948 of United Nations is considered as a model for all human rights documents and charters. This thirty article declaration has also prompted and influenced other subsequent constitutions of the world including Indian constitution of 1950. It was adopted on $10^{\text {th }}$ Dec. 1948 by General Assembly of the United Nations. Provisions of it constitute general principles of law of humanity (Bagde 2007).

The rights proclaimed by UDHR include right to life, liberty, security of person, equality before the law, privacy, marriage and protection of family life, social security, participation in government, work, protection against un employment, rest and leisure, a minimum standard of living, and enjoyment of arts, subject only to morality, public order and general welfare (Article
29.2).

As per Article 3 every one has right to life, liberty and security, while Article 4 states that no one shall be held in slavery or servitude. Some rights are claim rights and others are liberty rights as confirmed by Article 2 . According to Article 29.1 every one has duties to the community in which alone the free and full development of his personality is possible.

\section{Buddhist philosophy in relation to Universal Declaration Concept}

There is intimate and vital relationship of Buddhist norm of Dhamma with that of human Rights. Buddhist sees the concept of human rights as a legal extension of human nature and it is crystallization or formalization of mutual respect and concern of all persons, stemming from human nature. Few would disagree with the proposition that human rights are grounded in human nature and human nature is the ultimate source of human rights. Rights are actually extensions of human qualities such as security, liberty and life.

It seems that modern Western notions of human rights are compatible with Buddhist elements of human rights, as Buddhist principles endorse principles of Universal Declaration of human rights. Thus Buddhism subscribes to universal human rights concept without any reservation or exceptions and all the articles are in harmony with early Buddhist teachings in letter and spirit. Every Article of Human Rights has been adumbrated, cogently upheld and meaningfully incorporated in an overall view of life and society by Buddha. Early Buddhist teachings were in harmony with the spirit of Universal Declaration of Hunan Rights. There is a broad agreement that Buddhist teachings contribute to contemporary human rights movements. According to Kenneth Inada (1982) there is an intimate and vital relationship between Buddhist Dhamma and human Rights. It is human nature that is more basic and larger issue in comparison to human rights according to Buddhism. Human rights concept is legal extensionof human nature, it is indeed formalization of the mutual respect and concern for all persons which has stemmed from human nature. Therefore human rights are grounded in human nature. Human nature is the ultimate source of human rights and also rights are extensions of human qualities, like liberty, life and security. Also Buddhism credits the human personality with dignity and moral responsibility. Buddhism therefore contributes to an ethic of human rights.

Buddhist thought is in accord with Article1 of 1 of UDHR which states "all human beings are born free and equal in dignity and rights" and other Articles of UNDHR (Perera, 1991) for the advancement of human beings. Universal rights are consistent with Buddhist morality, the most persuasive argument being based on the Buddhist 
notion of compassion for all beings.

Dalai Lama, Buddhist Luminary and Philosopher on account of $50^{\text {th }}$ anniversary of UNDHR in1998 appealed that Buddhists must adopt an active approach to reduce suffering by active implementation of peace and human rights, including economic, social and cultural rights. Notions of rights have been derived from ethical principles and there is a clear convergence between Buddhists ethics and modern discussions on human rights. All human beings as per Buddhism are equal, and Buddhist concepts recognize the inherent dignity and the equal and inalienable rights of all human beings. Mane (2006).

Natural rights have been are inalienable, they are not conferred by any judicial or political process nor can they be removed by these or other means. These natural rights of $17^{\text {th }}$ and Eighteenth century are the forerunner of the contemporary notion of human rights. The concept of rights is virtually as old as civilization itself. Concept of right is implicit in classical Buddhism. All have reciprocal obligations which can be analyzed into rights and duties. Human rights were originally spoken of as natural rights. There seems to be nothing in any of the thirty articles of UNDHR to which Buddhism would take exception and they are in harmony with early Buddhist teachings both in letter and in spirit. Every Article of UNDHR even the labor rights to fair wages, leisure and welfare has been adumbrated, cogently upheld and meaningfully incorporated in an overall view of life and society by the Buddha. Hence, Buddhist teachings were in harmony with the spirit of Universal declaration of human Rights.

Unlike the article 2(7) of United Nations (UN) declaration in form of injunction placed for the interference in the domestic affairs of any sovereign state, Buddhism did not prescribe any such limitations. It travelled far and wide beyond Indian frontiers for the protection and restoration of human rights and fundamental freedom of the people of entire world.5 Buddhism was the custodian of human rights and fundamental freedom even before UN and other bodies became the custodians of human rights. Buddhism was the first religion to take active step against slavery, as Buddhist Monks were forbidden to keep slaves. They were also forbidden to accumulate wealth and own private property, forbidden from spiritual enslavement, Buddhism eliminated caste prejudice and hereditary distinctions between man and granted equal rights and equal status to every human being.

Buddhist penology contains the protection of human rights, human dignity and human worth, prescribing punishment but to bring transformation of the offenders' attitude and there is no place to retribution and sadism. The law of Buddha nips crime in the bud and therefore question of denial of human rights and fundamental freedom does not arise. Hence Buddhist Doctrine is supreme in comparison to the doctrine behind UDHR of UN of 1948. Buddhism indeed is supreme law of all laws existed so far in the province of human right protection and fundamental freedom. It transcends beyond the realm of humans and reaches out to entire realm of beings for their protection. Buddhist doctrine yielded tremendous influence upon the thinking of the civilization that existed twenty five centuries before the birth of UN and UNDHR. It restored human rights and fundamental freedom without the force of legislation but by the compassion or persuasion.

\section{The declaration of parliament of World's Religions}

A Parliament of the World's Religions was held in Chicago in September 1993, with the aim to find out basic moral teachings in most of the religions and to reach a consensus if possible on moral values. Most of the religions in the world were represented in this convention including ethnic and minority groups. This interfaith convention adopted a declaration called Declaration towards a Global Ethic, wherein fundamental moral principles subscribed by all the religions of the world were incorporated. These principles are mostly related to human rights and dignity.

Buddhist schools namely Theravaada, Mahaayaana, Vairayaana and Zen were party to the discussion and Dalai Lama gave closing address of the convention. Global Ethic states "we make a commitment to respect life and dignity, individuality and diversity, so that every person is treated humanely". Every human being possesses an inalienable and untouchable dignity. Human Rights as construed in the modern era are compatible with Buddhist ethics. Concept of human rights is historically contingent while the teachings of the Buddha are not and certainvalues embodied in the notion of right are better served by the notion of right in the Noble Eight fold Path as Human rights is an extension of human nature. Although there is no specific Sanskrit or Paliterm for the Western notion of rights the concept of rights is implicit in classical Buddhism.

Declaration towards Global Ethic has set out Fundamental moral principles which all religions of the world subscribe. Many of these principles are human Rights principles too. Hence Global Ethic sees the Universal recognition of human rights and dignity by the religions of the world, which is new global order. (Jayatilleke 1975).

\section{Essential elements of Human Rights in Buddhism}

Everyone has a role to play in sustaining and promoting social justice and orderliness. These rules are explained by Buddha very clearly as reciprocal duties with regard to parents and children, teachers and pupils, husband and wife, friends, relatives and neighbors, employer and employee, clergy and laity and no one has been left out. The duties are considered as sacred duties which create a just peaceful and harmonious society. Dharma therefore denotes not only what one is due to do but also what is due to one. 
Thus, it indicates duty and subsequent or correlative right of the person in Buddhism. Concept of rights is not alien to Buddhist philosophy. It is implied. All have duties in form of reciprocal obligations that could be analyzed as rights and duties. Dharma of Buddhism determines duties expressly and rights are implied in nature. A husband has a duty to support his wife, while wives have right to be maintained.This is also the case with respect to other civilizations, cultures and religions including Roman law. Duties of one correspond to the entitlements of rights of others. While king or political authority is to dispense justice impartially, citizens may be said to have a right to just and impartial treatment before the law. Therefore notion of a right is very much there in Buddhism. A right useful concept which provides justice, its correlative duty provides another.

Buddhism originated in caste based society. As per doctrine of Buddhism, there is no self, means all are equal in most profound sense. Similar to Christian doctrine that all men are created equal, Buddhism doctrine provides ground for natural rights, except incarnation ofthis concept in express terminology.

According to Dr. Ambedkar, religion based on God and caste system is not a religion. It creates love for God and hate for man. The religion necessarily must have four ingredients viz. liberty, equality, fraternity and morality. If these elements are absent in any religion, that religion cannot be a religion. In the Dhamma of Buddha all these elements are present. It is worth and not the birth that determines the status of man. Dr. Ambedkar has consciously embraced Buddhism, attracted by its doctrine of social and spiritual equality. According to great Scientist Albert Einstein Buddhism have characteristics of what would be expected in a cosmic religion for the future, it transcends a personal god, avoids dogmas and theology, it covers both the natural and spiritual characteristics. If there is any religion that could cope with scientific needs, it would be Buddhism.

Buddhist view of reciprocal obligations or duties can be seen as an embryonic form of rights or as preconditions for rights in the modern Western sense. Duties and rights are correlative and reciprocal. Buddhism is as such committed to the cause of human rights. Many of the rights and liberties spelt out in human Rights charters are present in either expressed or implied form in moral teachings of Buddha. Also theprohibitions of Buddhism coincide with those of the various human rights manifestoes, which may be regarded as translation of religious percepts into the language of rights. Percepts are however in form of duties that arise from dharma. Since duties have their correlative in rights, percepts seek to promote them. Person who has right has a benefit, which is either a claim or a liberty. As per percepts right holder is one who suffers from the breach of Dharmic duty. In this terminology the victim has a right to life while the aggressor has a duty to respect it. Five percepts in
Buddhism are fundamental principles for promoting and perpetuating human welfare, peace and justice in form of fivefold disciplinary code for man to maintain justice in society.

An apparent difference between the moral teachings of Buddhism and human rights, charters is one form rather than substance. Human Rights can be extrapolated from Buddhist moral teachings. Resultantly a direct translation of the first four percepts yields right to life, a right not to have one's property stolen, a right to fidelity in marriage and a right not to be lied to. Similarly a right not to be held in slavery is implicit in prohibition on trade in living beings. These rights are the extrapolation of what is due under dharma and they have not been imported in to Buddhism but were implicitly present.

The necessary basis of doctrine of human rights has been set out in the third and fourth noble truths of Buddhism. Hence doctrine of human rights is present in Buddhist philosophy and itis legitimate to speak of both rights and human rights in Buddhism. Modern doctrines of human rights are in harmony with the moral values of classical Buddhism. Human good is the preoccupation of both modern ideas of human rights and philosophies of religions including Buddhism.

There is a broad agreement that Buddhist teachings can make potential contribution to an ethic of human rights. Human rights as construed in the modern west are compatible with Buddhist ethics. It seems that Buddhism is committed to the cause of human rights. In Buddhism as well as western languages for right, equivalent word in pali is uju (or ujju) meaning straight, direct, straight forward, honest, although there is no word in Sanskrit or pali which conveys the idea of right or rights understood as a subjective entitlement. In African tribal regimes of law, right and duty are usually covered by the single word derived from the form normally translated as ought. Hence it seems concept of a right may exist to where a word for it does not. In Buddhism dharma determines what is right and just in all contexts and from all perspectives. In Buddhism duties are sacred and reciprocal. A duty of one corresponds to the entitlements or rights of others. It means notion of right is present in classical Buddhism. Buddhism endorses the universal declaration of human rights and the Articles are in harmony with early Buddhist teachings both in letter and spirit.

An intimate and vital relationship of the Buddhist norm or Dhamma is there with that of human rights. In Buddhism human rights issue is ancillary to the larger or more basic issue of human nature and the concept of human rights is a legal extension of human nature. It is crystallization and formalization of the mutual respect and concern of all persons, stemming from human nature and hence human rights are grounded in human nature.

The right to life is clearly fundamental since it is the condition for the enjoyment of all other rights and freedom. The right to liberty and security of person 
(Article- 3) is also basic to any understanding of human good as also slavery (Article -4), torture (Article -5) and the denial of right before the law (Article -6). Article -3 that no one shall be held in slavery is clearly implied in Article- 2. Thus, many of the thirty articles of UNDHR articulate the practical implication of a relatively small number of fundamental rights and freedom which are the basis of common good, human nature and its fulfillment, while Buddhism provides one view of human nature and its fulfillment. Similarly freedom of religion (Article-18) is vital to Buddhist vision. Human rights is an area in which religion have a legitimate and vital sake, and various human rights manifestos may be regarded as a translation of religious percepts into the language of rights. In this declaration lie enshrined certain values and norms emphasized by the major religions of the world.

Buddha started his mission of rebuilding the unjust social order on the pillars of love, compassion, maîtree, karuna, character, equality and brotherhood. Thus the foundation of Buddhism is based on human values, natural justice and equality. Contrary to the doctrine of inequality of Brahmanism, Buddha propounded the doctrine of equality, liberty and universal brotherhood. Buddha even recognized women's right to education and sociopolitical activity (Anand 2002). Buddha and Buddhism not only successfully revolted against the institution of caste but also provided an alternate way of life culture which is based on equality (Ambedkar 1999). Commenting on genesis of injustice and socioeconomic inequality in the Hindu social order $\mathrm{Dr}$ Ambedkar observed that men are borne equal is a doctrine repugnant to this social order as it does not admit the principle of equality and graded inequality is a fundamental principle. It recognizes slavery as a legal institution. Graded inequality has been in force in the economic life too. The first shall never become the last, not shall the last ever become the first.

This social order of inequality has been reversed in Buddhistsocial order. Buddha Dhamma has in it both hope as well as purpose. Its purpose is to remove Avijja means ignorance of the existence of suffering. There is hope in it because it shows the way to put an end to human sufferings. Twenty two vows administered by Dr. Ambedkar at the time of conversion to Buddhism in Nagpur, 1956 subscribe to believe in the principle that all human beings are equal and to endeavor to establish equality and he firmly believed that only Buddhism is Saddhamma. In fact it was not a conversion but liberation of Buddhists from Hinduism which was imposed upon them forcibly. The untouchables of today were the Buddhists of the ancient past because as per Dr. Ambedkar, conversion was their return to original faith to which they belonged in the ancient past. Atta Deepa Bhava of human society is the essence of whole teaching of Buddha, means be the light unto yourself. One's action is responsible for everything. In man's action lies his salvation. Dr. Babasaheb Ambedkar piloted the constitution of India and therein enshrined the principles of liberty, equality, fraternity and secularism. The very source of these principles for Dr. Ambedkar was the Dhamma of Buddha. Buddha Dhamma has been interpreted by Dr. Ambedkar in his true perspective as original and not reinterpreted.

The foundation of the Buddha Dhamma in Dr. Ambedkars view is man and the (right) relation of man to man in his life on the earth. Dhamma of Buddha is for removal of the sufferings and ignorance of the people. Dhamma of Buddha is morality and morality is Dhamma. One must practice virtues that must be accompanied by Prajna (understanding), and intelligence. Prajna must be accompanied with Karuna (compassion) and every act of Paramita (perfection) must be tested by PrajnaParamita (wisdom), consciousness of what is right and what wrong conduct is and there must be Sila (character) and Prajna for a man,Maitri(friendship) must be accompanied for the human beings and also for all living beings. The character of human society is also emphasized by Buddha through five percepts (Panchasila) which expects refraining from injuring, taking that which is not given, sexual immorality, lying and drunkenness. Buddhist monks are teachers in the society. Each monk of the Sangha had an equal right and dignity to vote for or against any activity pertaining to the order. This democracy was blossomed and borne fruits in Indian soil while it was still seedling in Greek.

A new approach with regard to human rights and Doctrine of Ahimsa (not harming) has been discussed by Byrne (2006) from an environmental perspective which is an exploration of the modern phenomenon of environmental Buddhism and the ethics related to the Doctrine of Ahimsa. Societies, cultures and even religious ideas must be capable of evolving and keeping pace to remain relevant for the modern era. In some cases, however, such evolution of fundamentals may reverse a principle into its opposite as seen in modern Buddhism. For instance killing one species to protect another in the name of conservation, an environmentalism may cross the Buddhism boundaries.

\section{CONCLUSION}

Human rights elements are incorporated in teachings of Buddhism extensively. It is a matter of understanding those various elements.

Duties have been expressed more prominently in Buddhism, while Corresponding rights are implied therein rather than expressed. Duties have been expressly included in Indian Constitution by Article-51A part IVA by $42^{\text {nd }}$ constitution Amendment Act 1975 and Human Rights have been included under fundamental Rights part III of the Indian constitution.Besides Human rights, duties 
have been also incorporated in constitutions of many countries.

Human Rights concept got evolved through right, moral rights, natural rights leading ultimately to more expanded modern concept of human rights.

There is intimate and vital relationship of Buddhist norm of Dhamma with that of human Rights. Buddhist sees the concept of human rights as a legal extension of human nature; it is crystallization or formalization of mutual respect and concern of all persons, stemming from human nature. Human rights are grounded in human nature and human nature is the ultimate source of human rights.

Every Article of Human Rights in UNDHR has been upheld and meaningfully incorporated in an overall view of life and society by Buddha. Early Buddhist teachings were in harmony with the spirit of Universal Declaration of Hunan Rights.

Parliament of World's Religions adopted a declaration called Declaration towards a Global Ethic, wherein fundamental moral principles subscribed by all the religions of the world were incorporated. These principles are mostly related to human rights and dignity.

Buddhism was the custodian of human rights and fundamental freedom. Buddhism was the first religion to take active step against slavery, as Buddhist Monks were forbidden to keep slaves. Buddhism eliminated caste prejudice and hereditary distinctions between man and granted equal rights and equal status to every human being (Ambedkar 1999).

Buddhist penology contains the protection of human rights, human dignity and human worth, prescribing punishment to bring transformation of the offenders' attitude without retribution and sadism.

Buddhist doctrine yielded tremendous influence upon the thinking of the civilization that existed twenty five centuries before the birth of UN and UNDHR and restored human rights and fundamental freedom.

Buddhist doctrine provides ground for natural rights, except incarnation of this concept in express terminology. The religion necessarily must have ingredients like liberty, equality, fraternity and morality. In the Dhamma of Buddha all these elements are present.

Social elements present in the message of Buddha are part and parcel of modern day principles of human Rights.

\section{REFERENCES}

Ambedkar BR (1984). The Buddha and his Dhamma, Third edition Bombay, Siddharth Publication. http://www.worldcat.org/title/buddhaand-his-dhamma/oclc/21766929?referer=di\&ht=edition

Ambedkar BR (1992). BabasahebAmbedkar's collected writings and speeches, Education Department of Govt. of Maharashtra, Eleventh 11:121-122

Ambedkar BR (1999). Annhilation of Caste. Ambedkar's collected writings and speeches Education Depart. Govt. Maharashtra. http://ccnmtl.columbia.edu/projects/mmt/ambedkar/web/

Ambedkar BR (1992). The Buddha and his Dhamma, First published in 1957, again published in 1979 (Education Department of Govt. of Maharashtra, Eleventh volume of Ambedkar's collected writings and speeches, 1992). http://www.wattpad.com/story/12099089-thebuddha-and-his-dhamma

Anand SK (2002). Buddha: The essence of Buddha and its practice Samruddha Bharat Publication, Mumbai, India.

Bagde US (2007). A comparative study of human rights in world constitutions, Mumbai: Aarti Book Company.

Byrne CJ (2006). 'Would A Buddhist Freeze A Cane Toad? An Exploration of the Modern Phenomenon of Environmental Buddhism and the Ethics Related to the Doctrine of Ahimsa (Non-harming)', Contemporary Buddhism, An Interdisciplinary J. 2(7):117-127. https://www.mugenproject.com/resources/45500

Demien K (1995). Are there Human Rights in Buddhism? J. Buddhist Ethics 2:3-27. http://www.pac-its.psu.edu/pub/jbe/acrobat/keown.pdf

Finnis JM (1980). Natural Law and Natural Rights. Clarenadon Law series, 2nd ed. London: Oxford. http://www.amazon.com/NaturalLaw-Rights-Clarendon/dp/0199599149

Jayatilleke KN (2010). The Buddhist attitude to other religions. The Wheel Publication No. 216. http://www.bps.lk/olib/wh/wh216.pdf

Kenneth KI (1990). A Buddhist response to the nature of human rights in Asian Perspectives on human rights, eds. Clavde E. Jr Welch and Virginia A. Leary, (Boulder, Co: Westview Press, pp.91-103.). http://www.tuvienquangduc.com.au/English/Ethics/25.nature.html

Mane S (2006). Glimpses of socio cultural revolts in India, Samrudh Bharat Publications, Social change $287 \mathrm{p}$. http://books.google.com.ng/books/about/Glimpses_of_Socio_cultural Revolts in In.html?id=908xMQAACAAJ\&redir esc $=y$

Perera LPN (1991). Buddhism and Human Rights. A Buddhist Commentary on the Universal Declaration of human rights. Karunaratne \& Sons, Buddhism $145 \mathrm{p}$. http://books.google.com.ng/books/about/Buddhism_and_Human_Rig hts.html?id=9u6FAAAAMAAJ\&redir_esc=y 